\title{
Therapeutic implications of cancer epithelial-mesenchymal transition (EMT)
}

\author{
Eunae Sandra $\mathrm{Cho}^{1} \cdot$ Hee Eun $\mathrm{Kang}^{1} \cdot$ Nam Hee Kim$^{1} \cdot$ Jong In $\operatorname{Yook}^{1}$ (i)
}

Received: 6 November 2018/Accepted: 27 December 2018/Published online: 16 January 2019

(C) The Author(s) 2019

\begin{abstract}
The epithelial-mesenchymal transition (EMT) comprises an essential biological process involving cancer progression as well as initiation. While the EMT has been regarded as a phenotypic conversion from epithelial to mesenchymal cells, recent evidence indicates that it plays a critical role in stemness, metabolic reprogramming, immune evasion and therapeutic resistance of cancer cells. Interestingly, several transcriptional repressors including Snail (SNAI1), Slug (SNAI2) and the ZEB family constitute key players for EMT in cancer as well as in the developmental process. Note that the dynamic conversion between EMT and epithelial reversion (mesenchymal-epithelial transition, MET) occurs through variable intermediate-hybrid states rather than being a binary process. Given the close connection between oncogenic signaling and EMT repressors, the EMT has emerged as a therapeutic target or goal (in terms of MET reversion) in cancer therapy. Here we review the critical role of EMT in therapeutic resistance and the importance of EMT as a therapeutic target for human cancer.
\end{abstract}

Keywords Epithelial-mesenchymal transition - EMT · Therapeutic resistance $\cdot$ Oncogenes $\cdot$ Snail $\cdot$ Wnt

Eunae Sandra Cho and Hee Eun Kang contributed equally.

Nam Hee Kim

migo77@yuhs.ac

$凶$ Jong In Yook

jiyook@yuhs.ac

1 Department of Oral Pathology, Oral Cancer Research Institute, Yonsei University College of Dentistry, Seoul 03722, Republic of Korea

\section{Introduction}

Traditionally, the concept of epithelial to mesenchymal transition (EMT) was mainly restricted to the reversible phenotypic transformation of epithelial to mesenchymal cells seen during development, wound healing and various diseases (Thiery et al. 2009). Reversible rounds of EMT and MET (mesenchymal to epithelial transition; the reverse state of EMT) constitute the physiologic stages of embryonic development with intense cell plasticity (Kalluri and Neilson 2003; Thiery et al. 2009). Pathological hyperactivated EMT has been widely described in tumor progression as invasive and metastatic cellular dissemination in the altered epithelium (Thiery 2002; Polyak and Weinberg 2009). After the single tumor cells are disseminated into the lymphatics or vasculature, MET is thought to be responsible for metastatic re-colonization in distant organs by regaining epithelial differentiation and proliferation ability (Chaffer et al. 2007).

The hallmark of EMT is the loss of epithelial marker expression, typically indicated by the presence of E-cadherin, with a gain in mesenchymal marker expression such as of N-cadherin and vimentin accompanied by invasive phenotype (Fig. 1). Epithelial cells are determined by apico-basal polarity, attachment to the basal lamina and tight cell-to-cell junctions, while mesenchymal cells are characterized as detached arrangements in the stroma with front-back polarity and migration ability (Thiery et al. 2009; Gonzalez and Medici 2014). The 'classic binary EMT' concept has been extended to a more comprehensive view of tumor progression, augmenting the traditional 'full phenotypic conversion' during invasion and metastasis (Hay 1995). EMT is now considered a more flexible status of plasticity known as the 'partial EMT program' rather 


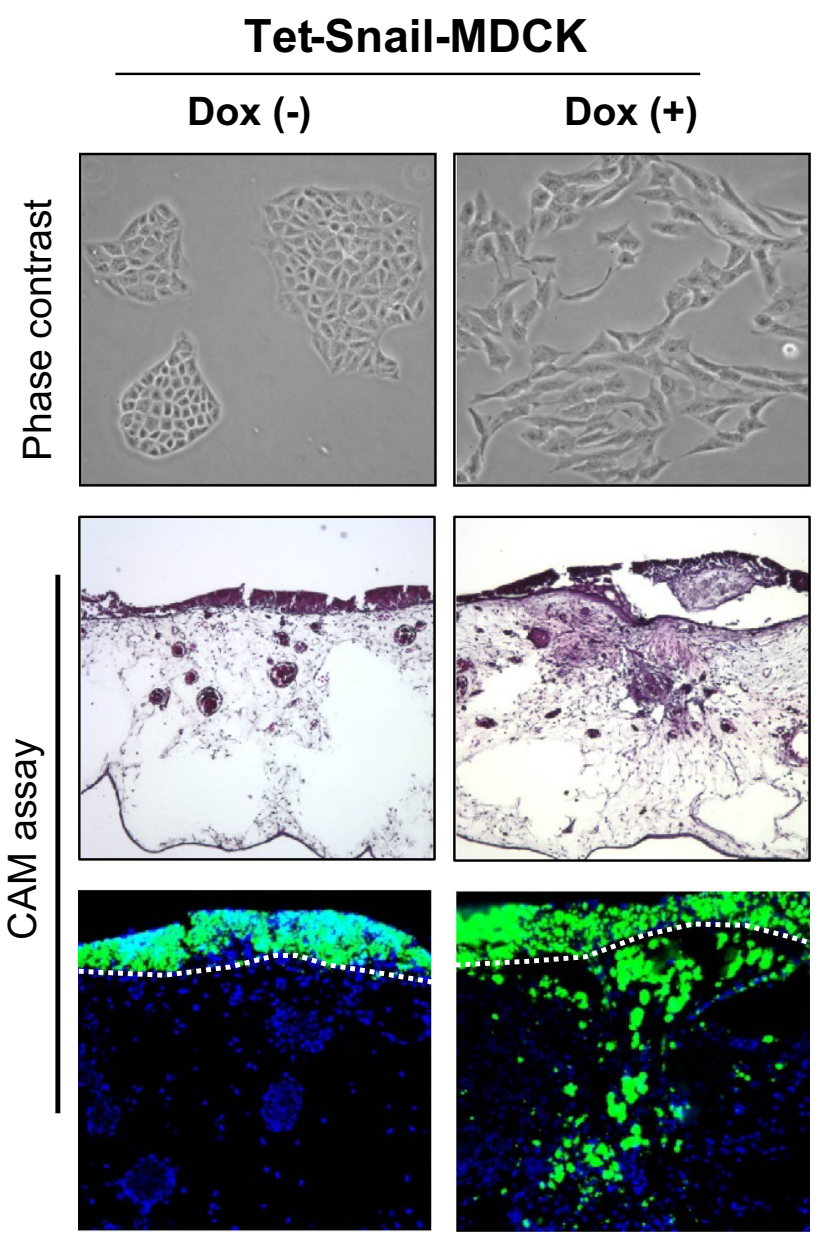

Fig. 1 Phenotypic transition and invasion induced by Snail in MDCK cells. The MDCK cells transduced with Tet-inducible Snail were treated with doxycycline for $72 \mathrm{~h}$; phase contrast images are shown (upper panels). The Snail-expressing MDCK cells were labeled with florescent beads (green) and cultured atop the chicken chorioalantoic membrane (CAM) for 3 days. The tissues were fixed, nuclei stained with DAPI (blue), and the frozen sections were examined by $\mathrm{H} / \mathrm{E}$ sections (middle panels) and fluorescence microscopy (lower panels). Dotted lines denote basement membrane of chorioalantoic membrane

than bearing full phenotypic transformation status during tumor progression (Nieto et al. 2016).

Transcriptional factors that directly or indirectly downregulate E-cadherin expression and induce EMT are known as EMT-activating transcriptional factors (EMT-TFs). EMT-TFs are tightly regulated via oncogenic signaling pathways consisting of non-coding RNAs, extracellular mediators and translational/post-translational regulations. In this review, we will summarize the pivotal molecular signaling pathways and therapeutic targets in cancer EMT.

\section{EMT-TFs and therapeutic resistance}

Snail family members (Snail [SNAI1] and Slug [SNAI2]) (Batlle et al. 2000; Cano et al. 2000; Hajra et al. 2002) and zinc-finger E-box binding (ZEB) family are well-known EMT-TFs. The EMT-TFs directly bind and suppress E-cadherin at the proximal $\mathrm{CDH} 1$ promoter and remodel intercellular adhesion (Craene and Berx 2013). Snail and ZEB also suppress other epithelial markers (e.g. claudins, occludins and desmoplakin), and activate mesenchymal genes (Moreno-Bueno et al. 2006; Vandewalle et al. 2009; Sanchez-Tillo et al. 2012). Furthermore, EMT-TFs are known to reorganize epithelial polarity molecules (Aigner et al. 2007; Spaderna et al. 2008) and impede basement membrane formation (Spaderna et al. 2006) to promote pro-invasive circumstances.

EMT-TFs (Snail in particular) are highly expressed in neoplastic nuclear tissue, adjacent stroma and peritumoral inflammation (Come et al. 2006; Franci et al. 2009; Tuhkanen et al. 2009; Bezdekova et al. 2012). Both Snail and ZEB are known to have correlation to clinical prognostic factors, e.g. aggressiveness, metastasis and poor survival, and have been reported to have chemoresistance for cisplatin, 5-fluorouracil, gefitinib, or doxorubicin (Witta et al. 2006; Arumugam et al. 2009; Hsu et al. 2010; Tryndyak et al. 2010; Chang et al. 2011; Haslehurst et al. 2012; Zhang et al. 2012). For example, induction of Snail significantly increases therapeutic resistance against the paclitaxel (taxol) treatment in breast cancer cells (Fig. 2), indicating that a higher Snail abundance is intimately associated with a worse therapeutic outcome of human cancer.

Recent immunotherapeutic approaches have provided remission in a significant number of cancer patients those were considered lethal previously. Not surprisingly, extensive molecular reprogramming by EMT and subsequent tumor microenvironment remodeling involves in

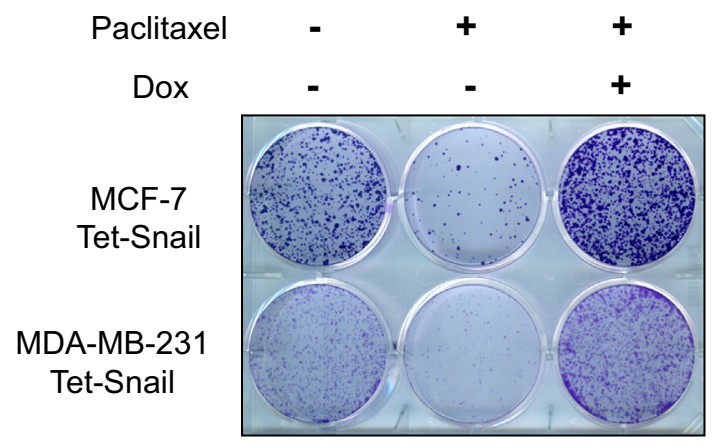

Fig. 2 Clonogenic survival of breast cancer cells against paclitaxel treatment. Clonogenic survival was determined by exposing cells to paclitaxel with induction of Snail (Dox + ) for $48 \mathrm{~h}$ followed by further observation in normal culture medium for 14 days and crystal violet staining 
therapeutic resistance to immunotherapeutics (Chockley and Keshamouni 2016). Indeed, TGF- $\beta$-mediated EMT promotes $\mathrm{T}$ cell exclusion and inhibition of TGF- $\beta$ with antibody or small molecules largely increased tumor response to PD-L1 blockade (Mariathasan et al. 2018; Tauriello et al. 2018).

\section{The molecular signaling pathways of EMT}

Intensive study over the past 2 decades has revealed many upstream regulators and oncogenic signaling pathways regulating EMT-TFs (Fig. 3). While many of these constitute EMT regulatory pathways [e.g. Wnt, Notch, Hedgehog $(\mathrm{HH})$, Transforming growth factor beta (TGF$\beta$ ), Receptor tyrosine kinase (RTK)s, and others], canonical Wnt and TGF- $\beta$ play critical roles in human malignancy and degenerative diseases.

The canonical Wnt signaling pathway induces Snail transcription and EMT via the $\beta$-catenin/T-cell factor (TCF)/LEF transcriptional complex. In normal condition, $\beta$-catenin is phosphorylated and consecutively degraded to maintain constant intracellular levels. The $\beta$-catenin phosphorylation is generally thought to result from a multiprotein 'destruction complex', which involves kinase proteins [glycogen synthase kinase-3 $\beta$ (GSK-3 $\beta$ ) and casein kinase $1(\mathrm{CK} 1)$ ] and scaffold proteins [Axin and adenomatous polyposis coli (APC)] in $\beta$-catenin dynamics (Fodde and Brabletz 2007). However, it should note that recent studies have supported the oncogenic role of Axin2 (Yochum 2012). Similar to $\beta$-catenin, the Snail harbors the GSK-3-dependent phosphorylation motif, ubiquitination and proteasomal degradation (Yook et al. 2005). Accordingly, canonical Wnt signaling inhibits Snail degradation via Axin2-mediated nuclear export of GSK-3 $\beta$ (Yook et al. 2006). Furthermore, the $\mathrm{Wnt} / \beta$-catenin axis promotes Slug activity and BRCA1 downregulation in breast cancer cells (Wu et al. 2012). Note that Axin2 and Snail are also highly expressed in precancerous colorectal adenomas and oral precancerous lesions (Lustig et al. 2002; Kroepil et al. 2012; Zhang et al. 2017).

Notch signaling directly activates EMT with nuclear translocation of the Notch intracellular domain (NICD). Jagged-2 (JAG2) and Notch interaction can extend to NCID cleavage by A Disintegrin and Metalloprotease (ADAM) protease and $\gamma$-secretase (Rizzo et al. 2008). NICD can bond to the Snail promoter and directly stimulates its expression (Wang et al. 2010). In addition, Notch can indirectly stabilize Snail1 activation by hypoxia-inducible factor $1 \alpha$ (HIF-1 $\alpha$ ) binding to the lysyl oxidase (LOX) promoter in hypoxic conditions (Sahlgren et al. 2008).

Hedgehog pathway, specifically the Shh, has been reported to contribute to tumor progression. Shh ligand

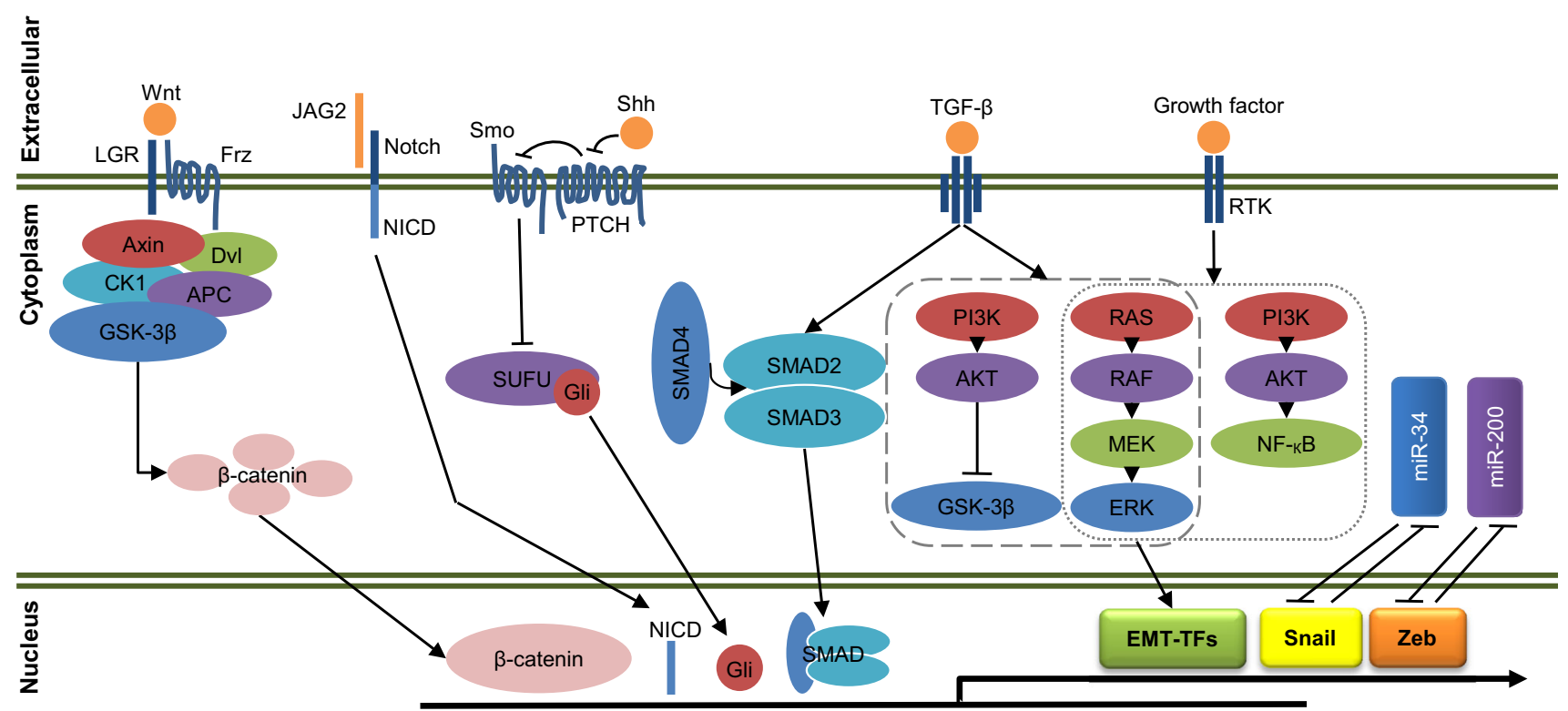

Fig. 3 Epithelial-mesenchymal transition (EMT) regulating pathways. EMT is regulated by several extracellular and intracellular pathways that promote EMT-transcriptional factors, Snail, ZEB and others. (Right to left: Wnt/ $\beta$-catenin/Snail, Notch/NICD/Snail1, Shh/Gli/Snail, TGF- $\beta /$ SMAD/Snail or ZEB, TGF- $\beta$ /non-SMAD/EMT-TFs, growth factor (e.g. EGF, FGF, HGF, IGF, PDGF)/RTK/EMT-TFs and reciprocal miRNA inhibition). $L G R$ low-density lipoprotein receptor-related protein, $F R Z$ frizzled, $D v l$ dishevelled, $C K-1$ Casein kinase 1 , GSK-3 $\beta$ glycogen synthase kinase-3 $\beta, A P C$ adenomatous polyposis coli, JAG2 Jagged-2, NICD notch intracellular domain, Shh sonic hedgehog, Smo smoothened, $P T C H$ patched homologs, SUFU suppressor of fused homolog, Gli Glioma, TGF- $\beta$ transforming growth factor beta, PI3K phosphoinositide 3-kinase, $E R K$ extracellular signal-regulated kinase, $R T K$ receptor tyrosine kinase, $N F-\kappa B$ nuclear factor kappa-light-chain-enhancer of activated $\mathrm{B}$ cells, EMT-TFs EMT-transcriptional factors, ZEB zinc finger E-box-binding homeobox, miR micro RNA 
binds to patched homolog (PTCH) receptors to activate Smoothened (Smo), which stimulates glioma (Gli) transcription factors (Briscoe and Therond 2013). Abberant Gli1 expression induced Snail and decreased E-cadherin expression in skin cancer ( $\mathrm{Li}$ et al. 2006). Moreover, Shh signaling has been seen to be associated with increased Snail expression in neuroendocrine tumor (Fendrich et al. 2007)

Together with Wnt signaling, the TGF- $\beta$ family is a representative EMT inducer in both development and disease through SMAD and non-SMAD regulated pathways. TGF- $\beta$ family ligands consist of three isoforms of TGF- $\beta$ and several BMPs, but so far only TGF- $\beta 1$ is known to participate in cancer (Akhurst and Derynck 2001). TGF- $\beta 1$ ligand and TGF- $\beta$ receptor (T $\beta$ R) II binding establish a phosphorylation cascade of $\mathrm{T} \beta \mathrm{R}$ I and SMAD2/3 oligomerized with SMAD4 as a trimer that enters the nucleus and leads to EMT gene reprogramming (Akhurst and Derynck 2001; Valcourt et al. 2005; Derynck et al. 2014). SMAD3/4 complex interacts with Snail at the nucleus in a SMAD3-dependent manner, suppressing E-cadherin and occludin expression (Vincent et al. 2009), although the molecular interaction between Snail and SMAD has not yet been clearly identified.

Non-SMAD signaling pathways induce EMT with translation regulation via the $\mathrm{PI} 3 \mathrm{~K} / \mathrm{AKT} / \mathrm{mTOR}$ pathway while RHO-GTPases decrease cellular junction and promote cytoskeletal remodeling (Katsuno et al. 2013; Derynck et al. 2014). Of these, mTOR complex 2 contributes to phenotypic transition, invasion and metastasis (Lamouille et al. 2012), while mTORC1 is responsible for increased intracellular synthesis and invasion (Lamouille and Derynck 2007). TGF- $\beta$ receptors also activate RAS/ RAF/MEK/ERK (extracellular signal-regulated kinase), which seems to contribute to EMT with loss of E-cadherin and Zonula occludens-1 (ZO-1) (Xie et al. 2004; Kang et al. 2009).

Various growth factors bind to receptor tyrosine kinases (RTKs) to promote EMT and tumorigenesis. RTKs can enhance TGF- $\beta 1$ expression in a positive feedback loop of autocrine signaling (Bennasroune et al. 2004; Lamouille et al. 2014). Epidermal growth factor (EGF) ligand can induce $\beta$-catenin and Snail transcription with loss of E-cadherin (Lu et al. 2003). Human EGFR 2 (HER2, a type of EGFR also named ERBB2) activation stimulated EMTmediated tumor progression and recurrence in mammary epithelial cells (Moody et al. 2005). Fibroblast growth factor-1 (FGF-1) and hepatocyte growth factor (HGF) increased Slug expression and desmosome dissociation in rat bladder carcinoma cells (Savagner et al. 1997). HGF binds with its RTK c-MET to induce Snail and Slug activation via the MAPK/ERK pathway (Grotegut et al. 2006). Insulin-like growth factor 1 (IGF1) is known to promote
EMT by activating NF- $\kappa B$-dependent Snaill activity or MAPK/ERK-mediated ZEB1 activity (Kim et al. 2007; Graham et al. 2008). In addition, IGF1 or an EGF ligand/ RTK bond stimulates EMT and cell migration with AKT and ERK pathway crosstalk (Irie et al. 2005). It should be noted that although targeted therapeutics against RTKs are in development worldwide in preclinical and clinical trials, the EMT is considered neither a biomarker nor a therapeutic outcome of RTK inhibitors.

\section{Non-coding RNA regulation in EMT}

In addition to gene-level regulation by EMT-TFs, RNAlevel regulation contributes to EMT mechanisms. In particular, non-coding RNAs known as microRNAs (miRNAs) are known for their either positive or negative interaction with EMT. The most famous two classes of miRNA known in EMT research are the miR-34 and miR200 families, which act as tumor suppressors (Korpal et al. 2008; Kim et al. 2011a). The p53/miR-34 axis and Wnt/ $\beta$ catenin pathway are linked in a tumor suppressor manner (Kim et al. 2011a). Moreover, Snail and ZEB1 have a double-negative feedback loop with miR-34 as well (Siemens et al. 2011). Interestingly, miR-34 targets the conserved sites at the untranslated regions of Wnt and Snail, revealing a close connection between p53 tumor suppressor and canonical Wnt signaling (Kim et al. 2011a; Siemens et al. 2011).

The miR-200 family (miR-200a, miR-200b, miR-200c, miR-141 and miR-429) is well-known for its reciprocal interactions with the ZEB family in cancer (Bracken et al. 2008; Gregory et al. 2008). As in miR-34, miR-200 is activated by p53 (Kim et al. 2011b) while the precise mechanisms of p53 and miRs need further investigation.

\section{Therapeutic development in EMT}

Two major approaches to specific targeting of RTKs or oncogenic signaling are monoclonal antibodies (mABs) and small molecule inhibitors (Imai and Takaoka 2006). We will review several, but not all, representative therapeutics controlling EMT that have been approved, are under clinical trial or are of significant importance (specific details are mentioned in Table 1).

The TGF- $\beta$ signaling pathway is a well-known target of EMT in various malignancies, its inhibitors having been widely investigated. Due to the importance of TGF- $\beta$ signaling in heart development, cardiovascular complications are an important concern in drug development (Anderton et al. 2011). Multiple small molecule inhibitors for TGF- $\beta$ ligands and receptors are currently going through clinical 
Table 1 Representative drug development targeting EMT

\begin{tabular}{|c|c|c|c|c|}
\hline Target & Therapeutics & $\begin{array}{l}\text { Clinical } \\
\text { status }\end{array}$ & Type of disease & Reference \\
\hline \multirow[t]{4}{*}{ TGF- $\beta$ ligands } & \multirow[t]{4}{*}{$\begin{array}{l}\text { Fresolimumab } \\
\quad(\text { GC-1008) }\end{array}$} & Phase I & Malignant melanoma or renal cell carcinoma & $\begin{array}{l}\text { Lacouture et al. (2015) } \\
\text { and Morris et al. } \\
\text { (2014) }\end{array}$ \\
\hline & & $\begin{array}{l}\text { Phase I, } \\
\text { II }\end{array}$ & NSCLC with SBRT & $\mathrm{NCT} 02581787^{\mathrm{a}}$ \\
\hline & & Phase II & Metastatic breast cancer with RT & $\mathrm{NCT} 01401062^{\mathrm{a}}$ \\
\hline & & Phase II & Malignant pleural mesothelioma & NCT01112293 \\
\hline \multirow[t]{3}{*}{ ALK1 } & \multirow[t]{3}{*}{ PF-03446962 } & Phase II & Advanced malignant pleural mesothelioma & $\begin{array}{l}\text { Wheatley-Price et al. } \\
\text { (2016) }\end{array}$ \\
\hline & & Phase I & $\mathrm{HCC}$ & Simonelli et al. (2016) \\
\hline & & Phase I & Advanced solid tumors & Goff et al. (2016) \\
\hline $\mathrm{T} \beta \mathrm{RI}$ & \multirow{6}{*}{$\begin{array}{l}\text { Galunisertib } \\
\text { (LY- } \\
2157299)\end{array}$} & Phase II & Recurrent glioblastoma & Brandes et al. (2016) \\
\hline \multirow[t]{5}{*}{$\mathrm{T} \beta \mathrm{RI}$} & & $\begin{array}{l}\text { Phase I, } \\
\text { II }\end{array}$ & Metastatic colorectal cancer with capecitabine & NCT03470350 \\
\hline & & Phase I & Metastatic and locally advanced pancreatic cancer & Ikeda et al. (2017) \\
\hline & & Phase I & Metastatic pancreatic cancer with durvalumab & NCT02734160 \\
\hline & & Phase I & HCC with sorafenib & NCT02240433 ${ }^{\mathrm{a}}$ \\
\hline & & Phase I & HCC with SBRT & NCT02906397 \\
\hline \multirow[t]{3}{*}{ EGFR } & $\begin{array}{l}\text { Erlotinib } \\
\quad\left(\text { Tarceva }^{\circledR}\right)\end{array}$ & $\begin{array}{l}\text { FDA- } \\
\text { app }\end{array}$ & NSCLC & Mayo et al. (2012) \\
\hline & $\begin{array}{l}\text { Gefitinib } \\
\quad\left(\text { Iressa }^{\circledR}\right)\end{array}$ & $\begin{array}{l}\text { FDA- } \\
\text { app }\end{array}$ & Metastatic NSCLC & $\begin{array}{l}\text { Murphy and Stordal } \\
\text { (2011) }\end{array}$ \\
\hline & $\begin{array}{l}\text { Lapatinib } \\
\quad\left(\text { Tykerb }^{\circledR}\right)\end{array}$ & $\begin{array}{l}\text { FDA- } \\
\text { app }\end{array}$ & Advanced or metastatic breast cancer & $\begin{array}{l}\text { Figueroa-Magalhaes } \\
\text { et al. (2014) }\end{array}$ \\
\hline \multirow{3}{*}{$\begin{array}{l}\text { PDGFR } \\
\text { VEGFR, } \\
\text { RAF (MKI) }\end{array}$} & \multirow[t]{3}{*}{$\begin{array}{l}\text { Sorafenib } \\
\quad\left(\text { Nexavar }^{\circledR}\right)\end{array}$} & $\begin{array}{l}\text { FDA- } \\
\text { app }\end{array}$ & Renal cell carcinoma & Wilhelm et al. (2006) \\
\hline & & $\begin{array}{l}\text { FDA- } \\
\text { app }\end{array}$ & Unresectable HCC & Lang (2008) \\
\hline & & $\begin{array}{l}\text { FDA- } \\
\text { app }\end{array}$ & Locally recurrent or metastatic, progressive and iodine-refractory DTC & $\begin{array}{l}\text { White and Cohen } \\
\text { (2015) }\end{array}$ \\
\hline $\begin{array}{l}\text { EGFR, } \\
\text { VEGFR, } \\
\text { RET(MKI) }\end{array}$ & $\begin{array}{l}\text { Vandetanib } \\
\quad\left(\text { Caprelsa }^{\circledR}\right)\end{array}$ & $\begin{array}{l}\text { FDA- } \\
\text { app }\end{array}$ & $\begin{array}{l}\text { Symptomatic or progressive MTC, unresectable locally advanced or } \\
\text { metastatic disease }\end{array}$ & Thornton et al. (2012) \\
\hline \multirow{2}{*}{$\begin{array}{l}\text { VEGFR, } \\
\text { PDGFR, } \\
\text { FGFR(MKI) }\end{array}$} & \multirow{2}{*}{$\begin{array}{l}\text { Nintedanib } \\
\quad\left(\text { Vargatef }^{(B)}\right)\end{array}$} & EU-app & NSCLC & Caglevic et al. (2015) \\
\hline & & $\begin{array}{l}\text { Phase I, } \\
\text { II }\end{array}$ & Advanced pancreatic cancer & NCT02902484 \\
\hline \multirow[t]{2}{*}{ Met } & \multirow[t]{2}{*}{ Onartuzumab } & $\begin{array}{l}\text { Phase } \\
\text { III }\end{array}$ & NSCLC with erlotinib & Spigel et al. (2017) \\
\hline & & $\begin{array}{l}\text { Phase } \\
\text { III }\end{array}$ & Gastroesophageal adenocarcinoma with combined CT & Shah et al. (2017) \\
\hline \multirow[t]{3}{*}{ Frizzled } & \multirow{3}{*}{$\begin{array}{l}\text { Vantictumab } \\
\text { (OMP-18R5) }\end{array}$} & Phase I & Recurrent or metastatic breast cancer with paclitaxel & NCT01973309 \\
\hline & & Phase I & Solid tumors & NCT01957007 \\
\hline & & Phase I & Stage IV pancreatic cancer & NCT02005315 \\
\hline \multirow[t]{2}{*}{ Wnt } & \multirow[t]{2}{*}{ Niclosamide } & $\begin{array}{l}\text { Phase I, } \\
\text { II }\end{array}$ & Colorectal cancer & $\begin{array}{l}\text { NCT02687009, } \\
\text { NCT02519582 }^{\mathrm{a}}\end{array}$ \\
\hline & & Phase I & Metastatic, recurrent and stage IV prostate cancer with enzalutamide & NCT03123978 \\
\hline \multirow[t]{2}{*}{ Notch } & \multirow[t]{2}{*}{$\begin{array}{l}\text { Tarextumab } \\
\quad(\text { OMP-59R5) }\end{array}$} & $\begin{array}{l}\text { Phase I, } \\
\text { II }\end{array}$ & Stage IV pancreatic cancer with combined CT & NCT01647828 \\
\hline & & $\begin{array}{l}\text { Phase I, } \\
\text { II }\end{array}$ & Small-cell lung cancer with combined CT & NCT01859741 ${ }^{\mathrm{a}}$ \\
\hline
\end{tabular}


Table 1 continued

\begin{tabular}{|c|c|c|c|c|}
\hline Target & Therapeutics & $\begin{array}{l}\text { Clinical } \\
\text { status }\end{array}$ & Type of disease & Reference \\
\hline \multirow[t]{7}{*}{$\gamma$-secretase } & \multirow[t]{4}{*}{$\begin{array}{r}\text { RO4929097 } \\
\text { (RG-4733) }\end{array}$} & Phase II & Metastatic pancreatic adenocarcinoma & $\begin{array}{l}\text { De Jesus-Acosta et al. } \\
\text { (2014) }\end{array}$ \\
\hline & & Phase II & Metastatic melanoma & Lee et al. (2015) \\
\hline & & Phase II & Recurrent ovarian cancer & $\begin{array}{l}\text { Diaz-Padilla et al. } \\
\text { (2015) }\end{array}$ \\
\hline & & Phase II & Metastatic colorectal cancer & Strosberg et al. (2012) \\
\hline & \multirow[t]{3}{*}{ MK-0752 } & $\begin{array}{l}\text { Phase I, } \\
\text { II }\end{array}$ & Metastatic breast cancer or advanced breast cancer & $\begin{array}{l}\text { NCT00645333 } \\
\text { NCT00106145 }^{\text {a }}\end{array}$ \\
\hline & & Phase I & Pancreatic cancer & NCT01098344 \\
\hline & & Phase I & Pedriatic brain tumor & Hoffman et al. (2015) \\
\hline Smoothened & $\begin{array}{l}\text { Vismodegib } \\
\quad\left(\text { Erivedg }^{\circledR}\right)\end{array}$ & $\begin{array}{l}\text { FDA- } \\
\text { app }\end{array}$ & Basal cell carcinoma & $\begin{array}{l}\text { Basset-Seguin et al. } \\
\text { (2015) }\end{array}$ \\
\hline \multirow[t]{2}{*}{ mTOR } & $\begin{array}{l}\text { Everolimus } \\
\quad(\text { Afinitor } \\
\end{array}$ & $\begin{array}{c}\text { FDA- } \\
\text { app }\end{array}$ & Renal cell carcinoma & $\begin{array}{l}\text { Vogelzang et al. } \\
\text { (2013) }\end{array}$ \\
\hline & $\begin{array}{l}\text { Temsirolimus } \\
\text { (Torisel }^{\circledR} \text { ) }\end{array}$ & $\begin{array}{l}\text { FDA- } \\
\text { app }\end{array}$ & Renal cell carcinoma & $\begin{array}{l}\text { Vogelzang et al. } \\
\text { (2013) }\end{array}$ \\
\hline $\mathrm{PI} 3 \mathrm{~K}$ & $\begin{array}{l}\text { Idelalisib } \\
\quad\left(\text { Zydelig }^{\circledR}\right)\end{array}$ & $\begin{array}{l}\text { FDA- } \\
\text { app }\end{array}$ & $\begin{array}{l}\text { Relapsed or refractory chronic lymphocytic leukemia with rituximab, } \\
\text { relapsed follicular lymphoma, and relapsed small lymphocytic } \\
\text { lymphoma }\end{array}$ & Yang et al. (2015) \\
\hline
\end{tabular}

For details, see the reference noted in the table

NSCLC non-small-cell lung carcinoma, SBRT stereotactic body radiotherapy, $C T$ chemotherapy, HCC Hepatocellular carcinoma, DTC differentiated thyroid cancer, $M T C$ medullary thyroid cancer, FDA Food and Drug Administration, EU European union, app approved, TGF- $\beta$ transforming growth factor beta, $T \beta R I$ TGF- $\beta$ receptor I, $A L K$ anaplastic lymphoma kinase, $M K I$ multi-kinase inhibitor, EGFR epidermal growth factor receptor, VEGFR vascular endothelial growth factor receptor, $P D G F R$ platelet-derived growth factor receptor, $F G F R$ fibroblast growth factor receptor

${ }^{\mathrm{a} U n i t e d ~ S t a t e s ~ N a t i o n a l ~ I n s t i t u t e s ~ o f ~ H e a l t h ~ C l i n i c a l ~ T r i a l ~ N u m b e r ~}$

trials. A mAB fresolimumab (GC-1008) that targets TGF- $\beta$ proteins has been or is currently in clinical trial. Phase I trials of malignant melanoma and renal cell carcinoma demonstrated its sufficient safety and anti-tumoral profiles (Morris et al. 2014). In another study, fresolimumab resolved skin lesions associated with malignant melanoma as well as renal cell carcinoma (Lacouture et al. 2015). Activin receptor-like kinase 1 (ALK1) is a TGF- $\beta$ serine/ threonine kinase receptor. A mAB of ALK1, named PF03446962, has been through clinical trials for several types of cancer with beneficial results for phase I, but not phase II (Goff et al. 2016; Simonelli et al. 2016; Wheatley-Price et al. 2016). Several TGF- $\beta$ I/II receptor kinase inhibitors are in pre-clinical research, namely EW-7203, EW-7197, and IN-1130 (Park et al. 2011, 2014; Son et al. 2014). A small molecule inhibitor which inhibits T $\beta$ RI, galunisertib (LY-2157299), was in phase Ib for metastatic or locally advanced pancreatic cancer and phase I and II for malignant glioma (Ikeda et al. 2017). It was first proposed for chemotherapy-resistant breast cancer which would not react to paclitaxel (Bhola et al. 2013). Galunisertib was reported to be free from cardiovascular adverse effects and benefitted near $1 / 5$ of the glioma patients enrolled (Rodon et al. 2015). Importantly, recent observations highlight the importance of TGF- $\beta$ inhibitors (galunisertib or TGF- $\beta$ blocking antibody) in combination with anti-PD1 (Programmed cell death protein 1)/PD-L1 (Programmed deathligand 1) immunotherapy (Mariathasan et al. 2018; Tauriello et al. 2018).

Tyrosine kinase inhibitors (TKIs) for RTKs are under active pre-clinical research and clinical assessment. TKIs may regulate a single RTK or simultaneously influence multiple RTKs. Representative US Food and Drug Administration-(FDA) approved TKIs for EGFR, gefitinib $\left(\right.$ Iressa ${ }^{\circledR}$ ) and erlotinib (Tarceva ${ }^{\circledR}$ ), achieved a $70 \%$ response rate in lung cancer (Mayo et al. 2012). They have been efficient in non-small cell lung cancer and ovarian cancer (Murphy and Stordal 2011). EGFR-targeted lapatinib $\left(\right.$ Tykerb $\left.^{\circledR}\right)$ and multi-TKI sorafenib (Nexavar ${ }^{\circledR}$ ), and vandetanib (Caprelsa ${ }^{\circledR}$ ) have been approved and provided for various malignancies (Wilhelm et al. 2006; Lang 2008; Thornton et al. 2012; Chau and Haddad 2013; FigueroaMagalhaes et al. 2014; Kuczynski et al. 2015; White and Cohen 2015). A triple-TKI nintedanib (Vargatef ${ }^{\circledR}$ ) that targets VEGFR (VEGF receptor), PDGFR (PDGF receptor) and FGFR (FGF receptor) has been approved for non- 
small-cell lung cancer in the European Union (Caglevic et al. 2015). A mAB onartuzumab, which targets MET in combination with other agents, has completed phase III in advanced solid tumors (Shah et al. 2017; Spigel et al. 2017), though it did not show improved clinical outcomes unlike its competent results in phase II of non-small-cell lung cancer (Spigel et al. 2013).

The Wnt/Frizzled ligand and receptor compound has fewer antibodies under clinical trial, yet active research is underway for therapeutic target development. Frizzledtargeted monoclonal antibody vantictumab (OMP-18R5) is going through phase I clinical trial with or without combined chemotherapeutics. Niclosamide $\left(\right.$ Niclocide $\left.^{\circledR}\right)$, a classic FDA-approved anthelmintic drug, has been reported to suppress the Wnt pathway in ovarian cancer (Arend et al. 2014) and familial adenomatosis polyposis (Ahn et al. 2017) in preclinical studies. The niclosamide can also target Notch, mTOR, and NF- $\mathrm{KB}$ signaling cascades to downregulate EMT characteristics in preclinical studies of glioblastoma (Wieland et al. 2013). It should note that targeting Frizzled receptor may a big huddle since there are 10 Frizzeled receptors while the oncogenic role of each receptor is not fully determined yet.

Notch-targeted monoclonal antibody tarextumab (OMP59R5) with or without combined chemotherapy is under phase I and II trials for various solid tumors. A $\gamma$-secretase inhibitor, RO4929097 (RG-4733), went through clinical trial phase II for metastatic pancreatic adenocarcinoma (De Jesus-Acosta et al. 2014), metastatic melanoma (Lee et al. 2015), recurrent ovarian cancer (Diaz-Padilla et al. 2015), and metastatic colorectal cancer (Strosberg et al. 2012) with minimal efficiency as a single agent. Another $\gamma$-secretase inhibitor, MK-0752, was in phase I for advance solid tumors with clinical benefits and tolerability (Krop et al. 2012; Hoffman et al. 2015).

\section{Considerations in EMT therapeutics}

EMT plays a key role in tumor progression and metastasis, which makes it an attractive target for cancer therapeutics. The regulatory mechanisms of multi-protein/transcriptional signaling pathways in EMT are extremely complex, with crosstalk and continuous reciprocal feedback loops. Drug development focusing on EMT is thus a complicated process and demands omnidirectional considerations.

EMT inhibitors may be compared with conventional chemotherapeutics or radiotherapy in terms of therapeutic efficacy during drug development, either alone or combined with conventional agents. Conventional chemotherapy and radiotherapy responses in vitro are evaluated through tumor proliferation inhibition and cancer cell cytotoxicity (Fan et al. 1998; Zoli et al. 2001). Clinical trials are typically evaluated based on the response evaluation criteria in solid tumors (RECIST) (Yoshida et al. 2015). In the revised version, non-measurable situations are assessed by tumor markers combined with other objective tumor responses (Eisenhauer et al. 2009). Nevertheless, EMT-targeted therapeutics should not be evaluated in the same way as conventional adjuvant chemotherapy. Note that tumor proliferation is attenuated in EMT and upregulated during MET and, noticeably, metastatic re-colonization (Zhu et al. 2014). Futhermore, in clinical tissue settings, EMT does not always gain its full transition state and may instead appear as 'partial EMT' expression (Nieto et al. 2016). Therefore, clinical assessment involving correlation between EMT marker expression and EMT-associated therapeutic efficacy needs further attention. The combination therapy with cytotoxic adjuvant chemotherapy or immunotherapy may an interesting option for EMT therapeutics. Several existing EMT-associated therapeutics were originally developed for other mechanisms than EMT and were evaluated using traditional methods. For example, assay systems for E-cadherin re-expression of cancer cells provided the interesting cancer therapeutics, such as salinomycin and protein kinase A (PKA) activators targeting cancer stem cells and EMT (Gupta et al. 2009; Pattabiraman et al. 2016).

\section{Concluding remarks}

Proliferative markers and cytotoxicity should be reconsidered as modes of action in EMT drug development. Screening assays for EMT-specific therapeutics are designed to select molecules that inhibit EMT phenotypic transition, invasiveness and metastatic properties without influencing proliferation potential (Marcucci et al. 2016). EMT markers discussed earlier, such as loss of E-cadherin, are effective in vitro while in vivo proof of concept for EMT-targeted therapeutic is under investigation. Future drug development for EMT should be applied using novel therapeutic targets, assessment measurements and therapeutic goals.

Acknowledgements We thank E. Tunkle for preparation of the manuscript. This work was supported by grants from the National Research Foundation of Korea (NRF-2017R1A2B3002241, NRF2016R1E1A1A01942724, NRF-2014R1A6A3A04055110, NRF2017R1C1B1012464) funded by the Korean government (MSIP) and a grant from the Korea Health Industry Development Institute (KHIDI) funded by the Ministry for Health \& Welfare Korea (HI17C2586).

\section{Compliance with ethical standards}

Conflict of interest The authors declare no conflict of interest.

Open Access This article is distributed under the terms of the Creative Commons Attribution 4.0 International License (http://crea tivecommons.org/licenses/by/4.0/), which permits unrestricted use, 
distribution, and reproduction in any medium, provided you give appropriate credit to the original author(s) and the source, provide a link to the Creative Commons license, and indicate if changes were made.

\section{References}

Ahn SY, Kim NH, Lee K, Cha YH, Yang JH, Cha SY, Cho ES, Lee Y, Cha JS, Cho HS, Jeon Y, Yuk YS, Cho S, No KT, Kim HS, Lee H, Choi J, Yook JI (2017) Niclosamide is a potential therapeutic for familial adenomatosis polyposis by disrupting axin-GSK3 interaction. Oncotarget 8:31842-31855

Aigner K, Dampier B, Descovich L, Mikula M, Sultan A, Schreiber M, Mikulits W, Brabletz T, Strand D, Obrist P, Sommergruber W, Schweifer N, Wernitznig A, Beug H, Foisner R, Eger A (2007) The transcription factor ZEB1 (deltaEF1) promotes tumour cell dedifferentiation by repressing master regulators of epithelial polarity. Oncogene 26:6979-6988

Akhurst RJ, Derynck R (2001) TGF-beta signaling in cancer-a double-edged sword. Trends Cell Biol 11:S44-51

Anderton MJ, Mellor HR, Bell A, Sadler C, Pass M, Powell S, Steele SJ, Roberts RR, Heier A (2011) Induction of heart valve lesions by small-molecule ALK5 inhibitors. Toxicol Pathol 39:916-924

Arend RC, Londono-Joshi AI, Samant RS, Li Y, Conner M, Hidalgo B, Alvarez RD, Landen CN, Straughn JM, Buchsbaum DJ (2014) Inhibition of Wnt/beta-catenin pathway by niclosamide: a therapeutic target for ovarian cancer. Gynecol Oncol 134:112-120

Arumugam T, Ramachandran V, Fournier KF, Wang H, Marquis L, Abbruzzese JL, Gallick GE, Logsdon CD, McConkey DJ, Choi W (2009) Epithelial to mesenchymal transition contributes to drug resistance in pancreatic cancer. Cancer Res 69:5820-5828

Basset-Seguin N, Hauschild A, Grob JJ, Kunstfeld R, Dreno B, Mortier L, Ascierto PA, Licitra L, Dutriaux C, Thomas L, Jouary T, Meyer N, Guillot B, Dummer R, Fife K, Ernst DS, Williams S, Fittipaldo A, Xynos I, Hansson J (2015) Vismodegib in patients with advanced basal cell carcinoma (STEVIE): a preplanned interim analysis of an international, open-label trial. Lancet Oncol 16:729-736

Batlle E, Sancho E, Franci C, Dominguez D, Monfar M, Baulida J, De Herreros AG (2000) The transcription factor snail is a repressor of E-cadherin gene expression in epithelial tumour cells. Nat Cell Biol 2:84-89

Bennasroune A, Gardin A, Aunis D, Cremel G, Hubert P (2004) Tyrosine kinase receptors as attractive targets of cancer therapy. Crit Rev Oncol Hematol 50:23-38

Bezdekova M, Brychtova S, Sedlakova E, Langova K, Brychta T, Belej K (2012) Analysis of Snail-1, E-cadherin and claudin-1 expression in colorectal adenomas and carcinomas. Int J Mol Sci 13:1632-1643

Bhola NE, Balko JM, Dugger TC, Kuba MG, Sanchez V, Sanders M, Stanford J, Cook RS, Arteaga CL (2013) TGF-beta inhibition enhances chemotherapy action against triple-negative breast cancer. J Clin Invest 123:1348-1358

Bracken CP, Gregory PA, Kolesnikoff N, Bert AG, Wang J, Shannon MF, Goodall GJ (2008) A double-negative feedback loop between ZEB1-SIP1 and the microRNA-200 family regulates epithelial-mesenchymal transition. Cancer Res 68:7846-7854

Brandes AA, Carpentier AF, Kesari S, Sepulveda-Sanchez JM, Wheeler HR, Chinot O, Cher L, Steinbach JP, Capper D, Specenier P, Rodon J, Cleverly A, Smith C, Gueorguieva I, Miles C, Guba SC, Desaiah D, Lahn MM, Wick W (2016) A phase II randomized study of galunisertib monotherapy or galunisertib plus lomustine compared with lomustine monotherapy in patients with recurrent glioblastoma. Neuro Oncol 18:1146-1156

Briscoe J, Therond PP (2013) The mechanisms of Hedgehog signalling and its roles in development and disease. Nat Rev Mol Cell Biol 14:416-429

Caglevic C, Grassi M, Raez L, Listi A, Giallombardo M, Bustamante E, Gil-Bazo I, Rolfo C (2015) Nintedanib in non-small cell lung cancer: from preclinical to approval. Ther Adv Respir Dis 9:164-172

Cano A, Perez-Moreno MA, Rodrigo I, Locascio A, Blanco MJ, del Barrio MG, Portillo F, Nieto MA (2000) The transcription factor snail controls epithelial-mesenchymal transitions by repressing E-cadherin expression. Nat Cell Biol 2:76-83

Chaffer CL, Thompson EW, Williams ED (2007) Mesenchymal to epithelial transition in development and disease. Cells Tissues Organs 185:7-19

Chang TH, Tsai MF, Su KY, Wu SG, Huang CP, Yu SL, Yu YL, Lan CC, Yang CH, Lin SB, Wu CP, Shih JY, Yang PC (2011) Slug confers resistance to the epidermal growth factor receptor tyrosine kinase inhibitor. Am J Respir Crit Care Med 183:1071-1079

Chau NG, Haddad RI (2013) Vandetanib for the treatment of medullary thyroid cancer. Clin Cancer Res 19:524-529

Chockley PJ, Keshamouni VG (2016) Immunological consequences of epithelial-mesenchymal transition in tumor progression. J Immunol 197:691-698

Come C, Magnino F, Bibeau F, De Santa Barbara P, Becker KF, Theillet C, Savagner P (2006) Snail and slug play distinct roles during breast carcinoma progression. Clin Cancer Res 12:5395-5402

Craene BD, Berx G (2013) Regulatory networks defining EMT during cancer initiation and progression. Nat Rev Cancer 13:97

De Jesus-Acosta A, Laheru D, Maitra A, Arcaroli J, Rudek MA, Dasari A, Blatchford PJ, Quackenbush K, Messersmith W (2014) A phase II study of the gamma secretase inhibitor RO4929097 in patients with previously treated metastatic pancreatic adenocarcinoma. Invest New Drugs 32:739-745

Derynck R, Muthusamy BP, Saeteurn KY (2014) Signaling pathway cooperation in TGF-beta-induced epithelial-mesenchymal transition. Curr Opin Cell Biol 31:56-66

Diaz-Padilla I, Wilson MK, Clarke BA, Hirte HW, Welch SA, Mackay HJ, Biagi JJ, Reedijk M, Weberpals JI, Fleming GF, Wang L, Liu G, Zhou C, Blattler C, Ivy SP, Oza AM (2015) A phase II study of single-agent RO4929097, a gamma-secretase inhibitor of Notch signaling, in patients with recurrent platinumresistant epithelial ovarian cancer: a study of the Princess Margaret, Chicago and California phase II consortia. Gynecol Oncol 137:216-222

Eisenhauer EA, Therasse P, Bogaerts J, Schwartz LH, Sargent D, Ford R, Dancey J, Arbuck S, Gwyther S, Mooney M, Rubinstein L, Shankar L, Dodd L, Kaplan R, Lacombe D, Verweij J (2009) New response evaluation criteria in solid tumours: revised RECIST guideline (version 1.1). Eur J Cancer 45:228-247

Fan W, Johnson KR, Miller MC 3rd (1998) In vitro evaluation of combination chemotherapy against human tumor cells (Review). Oncol Rep 5:1035-1042

Fendrich V, Waldmann J, Esni F, Ramaswamy A, Mullendore M, Buchholz M, Maitra A, Feldmann G (2007) Snail and Sonic Hedgehog activation in neuroendocrine tumors of the ileum. Endocr Relat Cancer 14:865-874

Figueroa-Magalhaes MC, Jelovac D, Connolly R, Wolff AC (2014) Treatment of HER2-positive breast cancer. Breast 23:128-136

Fodde R, Brabletz T (2007) Wnt/beta-catenin signaling in cancer stemness and malignant behavior. Curr Opin Cell Biol 19:150-158 
Franci C, Gallen M, Alameda F, Baro T, Iglesias M, Virtanen I, de Herreros AG (2009) Snaill protein in the stroma as a new putative prognosis marker for colon tumours. PLoS ONE 4:e5595

Goff LW, Cohen RB, Berlin JD, de Braud FG, Lyshchik A, Noberasco C, Bertolini F, Carpentieri M, Stampino CG, Abbattista A, Wang E, Borghaei H (2016) A phase I study of the anti-activin receptor-like kinase 1 (ALK-1) monoclonal antibody PF-03446962 in patients with advanced solid tumors. Clin Cancer Res 22:2146-2154

Gonzalez DM, Medici D (2014) Signaling mechanisms of the epithelial-mesenchymal transition. Sci Signal 7:re8

Graham TR, Zhau HE, Odero-Marah VA, Osunkoya AO, Kimbro KS, Tighiouart M, Liu T, Simons JW, O'Regan RM (2008) Insulinlike growth factor-I-dependent up-regulation of ZEB1 drives epithelial-to-mesenchymal transition in human prostate cancer cells. Cancer Res 68:2479-2488

Gregory PA, Bert AG, Paterson EL, Barry SC, Tsykin A, Farshid G, Vadas MA, Khew-Goodall Y, Goodall GJ (2008) The miR-200 family and miR-205 regulate epithelial to mesenchymal transition by targeting ZEB1 and SIP1. Nat Cell Biol 10:593-601

Grotegut S, von Schweinitz D, Christofori G, Lehembre F (2006) Hepatocyte growth factor induces cell scattering through MAPK/ Egr-1-mediated upregulation of Snail. EMBO J 25:3534-3545

Gupta PB, Onder TT, Jiang G, Tao K, Kuperwasser C, Weinberg RA, Lander ES (2009) Identification of selective inhibitors of cancer stem cells by high-throughput screening. Cell 138:645-659

Hajra KM, Chen DY, Fearon ER (2002) The SLUG zinc-finger protein represses E-cadherin in breast cancer. Cancer Res 62:1613-1618

Haslehurst AM, Koti M, Dharsee M, Nuin P, Evans K, Geraci J, Childs T, Chen J, Li J, Weberpals J, Davey S, Squire J, Park PC, Feilotter H (2012) EMT transcription factors snail and slug directly contribute to cisplatin resistance in ovarian cancer. BMC Cancer 12:91

Hay ED (1995) An overview of epithelio-mesenchymal transformation. Acta Anat (Basel) 154:8-20

Hoffman LM, Fouladi M, Olson J, Daryani VM, Stewart CF, Wetmore C, Kocak M, Onar-Thomas A, Wagner L, Gururangan S, Packer RJ, Blaney SM, Gajjar A, Kun LE, Boyett JM, Gilbertson RJ (2015) Phase I trial of weekly MK-0752 in children with refractory central nervous system malignancies: a pediatric brain tumor consortium study. Childs Nerv Syst 31:1283-1289

Hsu DS, Lan HY, Huang CH, Tai SK, Chang SY, Tsai TL, Chang CC, Tzeng CH, Wu KJ, Kao JY, Yang MH (2010) Regulation of excision repair cross-complementation group 1 by Snail contributes to cisplatin resistance in head and neck cancer. Clin Cancer Res 16:4561-4571

Ikeda M, Takahashi H, Kondo S, Lahn MMF, Ogasawara K, Benhadji KA, Fujii H, Ueno H (2017) Phase 1b study of galunisertib in combination with gemcitabine in Japanese patients with metastatic or locally advanced pancreatic cancer. Cancer Chemother Pharmacol 79:1169-1177

Imai K, Takaoka A (2006) Comparing antibody and small-molecule therapies for cancer. Nat Rev Cancer 6:714-727

Irie HY, Pearline RV, Grueneberg D, Hsia M, Ravichandran P, Kothari N, Natesan S, Brugge JS (2005) Distinct roles of Akt1 and Akt2 in regulating cell migration and epithelial-mesenchymal transition. J Cell Biol 171:1023-1034

Kalluri R, Neilson EG (2003) Epithelial-mesenchymal transition and its implications for fibrosis. J Clin Invest 112:1776-1784

Kang JS, Liu C, Derynck R (2009) New regulatory mechanisms of TGF-beta receptor function. Trends Cell Biol 19:385-394
Katsuno Y, Lamouille S, Derynck R (2013) TGF-beta signaling and epithelial-mesenchymal transition in cancer progression. Curr Opin Oncol 25:76-84

Kim HJ, Litzenburger BC, Cui X, Delgado DA, Grabiner BC, Lin X, Lewis MT, Gottardis MM, Wong TW, Attar RM, Carboni JM, Lee AV (2007) Constitutively active type I insulin-like growth factor receptor causes transformation and xenograft growth of immortalized mammary epithelial cells and is accompanied by an epithelial-to-mesenchymal transition mediated by NF-kappaB and snail. Mol Cell Biol 27:3165-3175

Kim NH, Kim HS, Kim NG, Lee I, Choi HS, Li XY, Kang SE, Cha SY, Ryu JK, Na JM, Park C, Kim K, Lee S, Gumbiner BM, Yook JI, Weiss SJ (2011a) p53 and microRNA-34 are suppressors of canonical Wnt signaling. Sci Signal 4:71

Kim T, Veronese A, Pichiorri F, Lee TJ, Jeon YJ, Volinia S, Pineau P, Marchio A, Palatini J, Suh SS, Alder H, Liu CG, Dejean A, Croce CM (2011b) p53 regulates epithelial-mesenchymal transition through microRNAs targeting ZEB1 and ZEB2. J Exp Med 208:875-883

Korpal M, Lee ES, Hu G, Kang Y (2008) The miR-200 family inhibits epithelial-mesenchymal transition and cancer cell migration by direct targeting of E-cadherin transcriptional repressors ZEB1 and ZEB2. J Biol Chem 283:14910-14914

Kroepil F, Fluegen G, Totikov Z, Baldus SE, Vay C, Schauer M, Topp SA, Esch JS, Knoefel WT, Stoecklein NH (2012) Downregulation of $\mathrm{CDH} 1$ is associated with expression of SNAI1 in colorectal adenomas. PLoS ONE 7:e46665

Krop I, Demuth T, Guthrie T, Wen PY, Mason WP, Chinnaiyan P, Butowski N, Groves MD, Kesari S, Freedman SJ, Blackman S, Watters J, Loboda A, Podtelezhnikov A, Lunceford J, Chen C, Giannotti M, Hing J, Beckman R, Lorusso P (2012) Phase I pharmacologic and pharmacodynamic study of the gamma secretase (Notch) inhibitor MK-0752 in adult patients with advanced solid tumors. J Clin Oncol 30:2307-2313

Kuczynski EA, Lee CR, Man S, Chen E, Kerbel RS (2015) Effects of sorafenib dose on acquired reversible resistance and toxicity in hepatocellular carcinoma. Cancer Res 75:2510-2519

Lacouture ME, Morris JC, Lawrence DP, Tan AR, Olencki TE, Shapiro GI, Dezube BJ, Berzofsky JA, Hsu FJ, Guitart J (2015) Cutaneous keratoacanthomas/squamous cell carcinomas associated with neutralization of transforming growth factor beta by the monoclonal antibody fresolimumab (GC1008). Cancer Immunol Immunother 64:437-446

Lamouille S, Derynck R (2007) Cell size and invasion in TGF-betainduced epithelial to mesenchymal transition is regulated by activation of the mTOR pathway. J Cell Biol 178:437-451

Lamouille S, Connolly E, Smyth JW, Akhurst RJ, Derynck R (2012) TGF-beta-induced activation of mTOR complex 2 drives epithelial-mesenchymal transition and cell invasion. J Cell Sci 125:1259-1273

Lamouille S, Xu J, Derynck R (2014) Molecular mechanisms of epithelial-mesenchymal transition. Nat Rev Mol Cell Biol 15:178-196

Lang L (2008) FDA approves sorafenib for patients with inoperable liver cancer. Gastroenterology 134:379

Lee SM, Moon J, Redman BG, Chidiac T, Flaherty LE, Zha Y, Othus M, Ribas A, Sondak VK, Gajewski TF, Margolin KA (2015) Phase 2 study of RO4929097, a gamma-secretase inhibitor, in metastatic melanoma: SWOG 0933. Cancer 121:432-440

Li X, Deng W, Nail CD, Bailey SK, Kraus MH, Ruppert JM, LoboRuppert SM (2006) Snail induction is an early response to Gli1 that determines the efficiency of epithelial transformation. Oncogene 25:609-621

Lu Z, Ghosh S, Wang Z, Hunter T (2003) Downregulation of caveolin-1 function by EGF leads to the loss of E-cadherin, 
increased transcriptional activity of beta-catenin, and enhanced tumor cell invasion. Cancer Cell 4:499-515

Lustig B, Jerchow B, Sachs M, Weiler S, Pietsch T, Karsten U, van de Wetering M, Clevers H, Schlag PM, Birchmeier W, Behrens J (2002) Negative feedback loop of Wnt signaling through upregulation of conductin/axin2 in colorectal and liver tumors. Mol Cell Biol 22:1184-1193

Marcucci F, Stassi G, De Maria R (2016) Epithelial-mesenchymal transition: a new target in anticancer drug discovery. Nat Rev Drug Discovery 15:311

Mariathasan S, Turley SJ, Nickles D, Castiglioni A, Yuen K, Wang Y, Kadel EE III, Koeppen H, Astarita JL, Cubas R, Jhunjhunwala S, Banchereau R, Yang Y, Guan Y, Chalouni C, Ziai J, Senbabaoglu Y, Santoro S, Sheinson D, Hung J, Giltnane JM, Pierce AA, Mesh K, Lianoglou S, Riegler J, Carano RAD, Eriksson P, Hoglund M, Somarriba L, Halligan DL, van der Heijden MS, Loriot Y, Rosenberg JE, Fong L, Mellman I, Chen DS, Green M, Derleth C, Fine GD, Hegde PS, Bourgon R, Powles T (2018) TGFbeta attenuates tumour response to PD-L1 blockade by contributing to exclusion of T cells. Nature 554:544-548

Mayo C, Bertran-Alamillo J, Molina-Vila MA, Gimenez-Capitan A, Costa C, Rosell R (2012) Pharmacogenetics of EGFR in lung cancer: perspectives and clinical applications. Pharmacogenomics 13:789-802

Moody SE, Perez D, Pan TC, Sarkisian CJ, Portocarrero CP, Sterner CJ, Notorfrancesco KL, Cardiff RD, Chodosh LA (2005) The transcriptional repressor Snail promotes mammary tumor recurrence. Cancer Cell 8:197-209

Moreno-Bueno G, Cubillo E, Sarrio D, Peinado H, Rodriguez-Pinilla SM, Villa S, Bolos V, Jorda M, Fabra A, Portillo F, Palacios J, Cano A (2006) Genetic profiling of epithelial cells expressing E-cadherin repressors reveals a distinct role for Snail, Slug, and E47 factors in epithelial-mesenchymal transition. Cancer Res 66:9543-9556

Morris JC, Tan AR, Olencki TE, Shapiro GI, Dezube BJ, Reiss M, Hsu FJ, Berzofsky JA, Lawrence DP (2014) Phase I study of GC1008 (fresolimumab): a human anti-transforming growth factor-beta (TGFbeta) monoclonal antibody in patients with advanced malignant melanoma or renal cell carcinoma. PLoS ONE 9:e90353

Murphy M, Stordal B (2011) Erlotinib or gefitinib for the treatment of relapsed platinum pretreated non-small cell lung cancer and ovarian cancer: a systematic review. Drug Resist Updat 14:177-190

Nieto MA, Huang RY, Jackson RA, Thiery JP (2016) EMT: 2016. Cell 166:21-45

Park CY, Kim DK, Sheen YY (2011) EW-7203, a novel small molecule inhibitor of transforming growth factor-beta (TGFbeta) type I receptor/activin receptor-like kinase-5, blocks TGFbeta1-mediated epithelial-to-mesenchymal transition in mammary epithelial cells. Cancer Sci 102:1889-1896

Park CY, Min KN, Son JY, Park SY, Nam JS, Kim DK, Sheen YY (2014) An novel inhibitor of TGF-beta type I receptor, IN-1130, blocks breast cancer lung metastasis through inhibition of epithelial-mesenchymal transition. Cancer Lett 351:72-80

Pattabiraman DR, Bierie B, Kober KI, Thiru P, Krall JA, Zill C, Reinhardt F, Tam WL, Weinberg RA (2016) Activation of PKA leads to mesenchymal-to-epithelial transition and loss of tumorinitiating ability. Science 351:aad3680

Polyak K, Weinberg RA (2009) Transitions between epithelial and mesenchymal states: acquisition of malignant and stem cell traits. Nat Rev Cancer 9:265-273

Rizzo P, Osipo C, Foreman K, Golde T, Osborne B, Miele L (2008) Rational targeting of Notch signaling in cancer. Oncogene 27:5124-5131
Rodon J, Carducci MA, Sepulveda-Sanchez JM, Azaro A, Calvo E, Seoane J, Brana I, Sicart E, Gueorguieva I, Cleverly AL, Pillay NS, Desaiah D, Estrem ST, Paz-Ares L, Holdhoff M, Blakeley J, Lahn MM, Baselga J (2015) First-in-human dose study of the novel transforming growth factor-beta receptor I kinase inhibitor LY2157299 monohydrate in patients with advanced cancer and glioma. Clin Cancer Res 21:553-560

Sahlgren C, Gustafsson MV, Jin S, Poellinger L, Lendahl U (2008) Notch signaling mediates hypoxia-induced tumor cell migration and invasion. Proc Natl Acad Sci USA 105:6392-6397

Sanchez-Tillo E, Liu Y, de Barrios O, Siles L, Fanlo L, Cuatrecasas M, Darling DS, Dean DC, Castells A, Postigo A (2012) EMTactivating transcription factors in cancer: beyond EMT and tumor invasiveness. Cell Mol Life Sci 69:3429-3456

Savagner P, Yamada KM, Thiery JP (1997) The zinc-finger protein slug causes desmosome dissociation, an initial and necessary step for growth factor-induced epithelial-mesenchymal transition. J Cell Biol 137:1403-1419

Shah MA, Bang YJ, Lordick F, Alsina M, Chen M, Hack SP, Bruey JM, Smith D, McCaffery I, Shames DS, Phan S, Cunningham D (2017) Effect of Fluorouracil, leucovorin, and oxaliplatin with or without onartuzumab in HER2-negative, MET-positive gastroesophageal adenocarcinoma: the METGastric randomized clinical trial. JAMA Oncol 3:620-627

Siemens H, Jackstadt R, Hunten S, Kaller M, Menssen A, Gotz U, Hermeking H (2011) miR-34 and SNAIL form a double-negative feedback loop to regulate epithelial-mesenchymal transitions. Cell Cycle 10:4256-4271

Simonelli M, Zucali P, Santoro A, Thomas MB, de Braud FG, Borghaei H, Berlin J, Denlinger CS, Noberasco C, Rimassa L, Kim TY, English PA, Abbattista A, Stampino CG, Carpentieri M, Williams JA (2016) Phase I study of PF-03446962, a fully human monoclonal antibody against activin receptor-like kinase1 , in patients with hepatocellular carcinoma. Ann Oncol 27:1782-1787

Son JY, Park SY, Kim SJ, Lee SJ, Park SA, Kim MJ, Kim SW, Kim DK, Nam JS, Sheen YY (2014) EW-7197, a novel ALK-5 kinase inhibitor, potently inhibits breast to lung metastasis. Mol Cancer Ther 13:1704-1716

Spaderna S, Schmalhofer O, Hlubek F, Berx G, Eger A, Merkel S, Jung A, Kirchner T, Brabletz T (2006) A transient, EMT-linked loss of basement membranes indicates metastasis and poor survival in colorectal cancer. Gastroenterology 131:830-840

Spaderna S, Schmalhofer O, Wahlbuhl M, Dimmler A, Bauer K, Sultan A, Hlubek F, Jung A, Strand D, Eger A, Kirchner T, Behrens J, Brabletz T (2008) The transcriptional repressor ZEB1 promotes metastasis and loss of cell polarity in cancer. Cancer Res 68:537-544

Spigel DR, Ervin TJ, Ramlau RA, Daniel DB, Goldschmidt JH Jr, Blumenschein GR Jr, Krzakowski MJ, Robinet G, Godbert B, Barlesi F, Govindan R, Patel T, Orlov SV, Wertheim MS, Yu W, Zha J, Yauch RL, Patel PH, Phan SC, Peterson AC (2013) Randomized phase II trial of Onartuzumab in combination with erlotinib in patients with advanced non-small-cell lung cancer. J Clin Oncol 31:4105-4114

Spigel DR, Edelman MJ, O’Byrne K, Paz-Ares L, Mocci S, Phan S, Shames DS, Smith D, Yu W, Paton VE, Mok T (2017) Results from the phase III randomized trial of onartuzumab plus erlotinib versus erlotinib in previously treated stage IIIB or IV non-smallcell lung cancer: METLung. J Clin Oncol 35:412-420

Strosberg JR, Yeatman T, Weber J, Coppola D, Schell MJ, Han G, Almhanna K, Kim R, Valone T, Jump H, Sullivan D (2012) A phase II study of RO4929097 in metastatic colorectal cancer. Eur J Cancer 48:997-1003

Tauriello DVF, Palomo-Ponce S, Stork D, Berenguer-Llergo A, Badia-Ramentol J, Iglesias M, Sevillano M, Ibiza S, Cañellas A, 
Hernando-Momblona X, Byrom D, Matarin JA, Calon A, Rivas EI, Nebreda AR, Riera A, Attolini CS, Batlle E (2018) TGFbeta drives immune evasion in genetically reconstituted colon cancer metastasis. Nature 554:538-543

Thiery JP (2002) Epithelial-mesenchymal transitions in tumour progression. Nat Rev Cancer 2:442-454

Thiery JP, Acloque H, Huang RYJ, Nieto MA (2009) Epithelialmesenchymal transitions in development and disease. Cell 139:871-890

Thornton K, Kim G, Maher VE, Chattopadhyay S, Tang S, Moon YJ, Song P, Marathe A, Balakrishnan S, Zhu H, Garnett C, Liu Q, Booth B, Gehrke B, Dorsam R, Verbois L, Ghosh D, Wilson W, Duan J, Sarker H, Miksinski SP, Skarupa L, Ibrahim A, Justice R, Murgo A, Pazdur R (2012) Vandetanib for the treatment of symptomatic or progressive medullary thyroid cancer in patients with unresectable locally advanced or metastatic disease: U.S. Food and Drug Administration drug approval summary. Clin Cancer Res 18:3722-3730

Tryndyak VP, Beland FA, Pogribny IP (2010) E-cadherin transcriptional down-regulation by epigenetic and microRNA-200 family alterations is related to mesenchymal and drug-resistant phenotypes in human breast cancer cells. Int J Cancer 126:2575-2583

Tuhkanen H, Soini Y, Kosma VM, Anttila M, Sironen R, Hamalainen K, Kukkonen L, Virtanen I, Mannermaa A (2009) Nuclear expression of Snail1 in borderline and malignant epithelial ovarian tumours is associated with tumour progression. BMC Cancer 9:289

Valcourt U, Kowanetz M, Niimi H, Heldin CH, Moustakas A (2005) TGF-beta and the Smad signaling pathway support transcriptomic reprogramming during epithelial-mesenchymal cell transition. Mol Biol Cell 16:1987-2002

Vandewalle C, Van Roy F, Berx G (2009) The role of the ZEB family of transcription factors in development and disease. Cell Mol Life Sci 66:773-787

Vincent T, Neve EP, Johnson JR, Kukalev A, Rojo F, Albanell J, Pietras K, Virtanen I, Philipson L, Leopold PL, Crystal RG, de Herreros AG, Moustakas A, Pettersson RF, Fuxe J (2009) A SNAIL1-SMAD3/4 transcriptional repressor complex promotes TGF-beta mediated epithelial-mesenchymal transition. Nat Cell Biol 11:943-950

Vogelzang NJ, Bhor M, Liu Z, Dhanda R, Hutson TE (2013) Everolimus vs. temsirolimus for advanced renal cell carcinoma: use and use of resources in the US Oncology Network. Clin Genitourin Cancer 11:115-120

Wang Z, Li Y, Kong D, Sarkar FH (2010) The role of Notch signaling pathway in epithelial-mesenchymal transition (EMT) during development and tumor aggressiveness. Curr Drug Targets 11:745-751

Wheatley-Price P, Chu Q, Bonomi M, Seely J, Gupta A, Goss G, Hilton J, Feld R, Lee CW, Goffin JR, Maksymiuk A, Murray N, Hagerman L, Bradbury PA (2016) A phase II study of PF03446962 in patients with advanced malignant pleural mesothelioma. CCTG Trial IND.207. J Thorac Oncol 11:2018-2021

White PT, Cohen MS (2015) The discovery and development of sorafenib for the treatment of thyroid cancer. Expert Opin Drug Discov 10:427-439

Wieland A, Trageser D, Gogolok S, Reinartz R, Hofer H, Keller M, Leinhaas A, Schelle R, Normann S, Klaas L, Waha A, Koch P, Fimmers R, Pietsch T, Yachnis AT, Pincus DW, Steindler DA, Brustle O, Simon M, Glas M, Scheffler B (2013) Anticancer effects of niclosamide in human glioblastoma. Clin Cancer Res 19:4124-4136

Wilhelm S, Carter C, Lynch M, Lowinger T, Dumas J, Smith RA, Schwartz B, Simantov R, Kelley S (2006) Discovery and development of sorafenib: a multikinase inhibitor for treating cancer. Nat Rev Drug Discov 5:835-844

Witta SE, Gemmill RM, Hirsch FR, Coldren CD, Hedman K, Ravdel L, Helfrich B, Dziadziuszko R, Chan DC, Sugita M, Chan Z, Baron A, Franklin W, Drabkin HA, Girard L, Gazdar AF, Minna JD, Bunn PA Jr (2006) Restoring E-cadherin expression increases sensitivity to epidermal growth factor receptor inhibitors in lung cancer cell lines. Cancer Res 66:944-950

Wu ZQ, Li XY, Hu CY, Ford M, Kleer CG, Weiss SJ (2012) Canonical Wnt signaling regulates Slug activity and links epithelial-mesenchymal transition with epigenetic breast cancer 1, early onset (BRCA1) repression. Proc Natl Acad Sci USA 109:16654-16659

Xie L, Law BK, Chytil AM, Brown KA, Aakre ME, Moses HL (2004) Activation of the Erk pathway is required for TGF-beta1-induced EMT in vitro. Neoplasia 6:603-610

Yang Q, Modi P, Newcomb T, Queva C, Gandhi V (2015) Idelalisib: first-in-class PI3K delta inhibitor for the treatment of chronic lymphocytic leukemia, small lymphocytic leukemia, and follicular lymphoma. Clin Cancer Res 21:1537-1542

Yochum GS (2012) AXIN2: tumor suppressor, oncogene or both in colorectal cancer? J Cancer Sci Therapy 4:7-8

Yook JI, Li XY, Ota I, Fearon ER, Weiss SJ (2005) Wnt-dependent regulation of the E-cadherin repressor snail. J Biol Chem 280:11740-11748

Yook JI, Li XY, Ota I, Hu C, Kim HS, Kim NH, Cha SY, Ryu JK, Choi YJ, Kim J, Fearon ER, Weiss SJ (2006) A Wnt-Axin2GSK3beta cascade regulates Snaill activity in breast cancer cells. Nat Cell Biol 8:1398-1406

Yoshida T, Yoh K, Niho S, Umemura S, Matsumoto S, Ohmatsu H, Ohe Y, Goto K (2015) RECIST progression patterns during EGFR tyrosine kinase inhibitor treatment of advanced non-small cell lung cancer patients harboring an EGFR mutation. Lung Cancer 90:477-483

Zhang W, Feng M, Zheng G, Chen Y, Wang X, Pen B, Yin J, Yu Y, He Z (2012) Chemoresistance to 5-fluorouracil induces epithelial-mesenchymal transition via up-regulation of Snail in MCF7 human breast cancer cells. Biochem Biophys Res Commun 417:679-685

Zhang X, Kim KY, Zheng Z, Kim HS, Cha IH, Yook JI (2017) Snail and Axin2 expression predict the malignant transformation of oral leukoplakia. Oral Oncol 73:48-55

Zhu Y, Luo M, Brooks M, Clouthier SG, Wicha MS (2014) Biological and clinical significance of cancer stem cell plasticity. Clin Transl Med 3:32

Zoli W, Ricotti L, Tesei A, Barzanti F, Amadori D (2001) In vitro preclinical models for a rational design of chemotherapy combinations in human tumors. Crit Rev Oncol Hematol 37:69-82

\section{Publisher's Note}

Springer Nature remains neutral with regard to jurisdictional claims in published maps and institutional affiliations. 